\title{
ANWAR AS-SĀDĀT USHERS IN A NEW ERA IN SOVIET-EGYPTIAN RELATIONS, 1970 - $1971^{1}$
}

\author{
Karol R. SORBY \\ Institute of Oriental Studies, Slovak Academy of Sciences, \\ Klemensova 19, 81364 Bratislava, Slovakia \\ Karol.Sorby@savba.sk
}

The choice of Anwar as-Sādāt as President of Egypt was confirmed by plebiscite on 15 October 1970. His era marked a radical shift in the underlying aims of Egypt's internal and external policies. In order to understand the nature of the goals, means and style of Sadat's policy, with its consequences for Soviet-Egyptian relations, it is necessary to focus on his perception of international and regional politics, including, for example, the moves of the superpowers towards détente, the military balance between Israel and the Arab countries; and competition within the Arab world. Anwar as-Sādāt had his own methods of manipulating the constraints on Egypt and using his capabilities in developing foreign policy at the local, regional and global levels.

Keywords: The death of Jamāl 'Abdannāșir; Anwar as-Sādāt becomes president; the Soviets are assessing the situation; renewal of the cease fire; struggles inside the UN; Egypt's need of modern weapons; as-Sādāt's peace initiative fails; Soviet-Egyptian treaty of friendship.

The Soviet leaders quickly reaffirmed their friendship for the collective leadership in Cairo. From their point of view, the most serious question was who would be the new Egyptian leader. A large delegation of government and Communist Party of the Soviet Union (CPSU) representatives led by Prime Minister Alexey Kosygin and including First Deputy Defence Minister Marshal Matvey Zakharov and Colonel General Vasiliy Okunev (a specialist on missiles and air defence), attended the funeral of President Jamāl ' Abdannāșir. The visitors remained in Cairo for several days of meetings with Egypt's new leadership, which was headed by acting president Anwar as-Sādāt. They conveyed Moscow's deep interest in a stable Egypt and its assurance of noninterference. However, they had two grounds for anxiety: the possible rivalries

${ }^{1}$ This study is published within the VEGA 2/0028/18 grant project. 
between the new leaders of Egypt, and the decision to rush into a new conflict with Israel. $^{2}$ The joint communiqué released on 3 October 1970 at the end of the visit pledged continued Soviet-Egyptian cooperation and appealed for the Arabs to achieve success in their just struggle for national independence, progress and a rapid solution of the Middle East conflict. It stated that both governments "have always regarded friendly relations between themselves as a permanent factor unaffected by changes in the international situation" and that they were resolved to continue strengthening their relationship. ${ }^{3}$ The USSR agreed to provide new support and accelerate arms deliveries contracted for 1971, in order to show that it stood by Egypt. ${ }^{4}$ Everybody inside and outside Egypt - and among foreign governments those especially of the USA and USSR - was eager to find out what Egypt was now going to be like. Egypt's relation with the Americans could best be described as a sort of uneasy truce. ${ }^{5}$

Immediately on taking office, Anwar as-Sādāt recognized that a further war against Israel, albeit limited in scale, would be unavoidable if the Arab-Israeli conflict was to be resolved on a just basis. He therefore set in motion five courses of action: a) satisfying Egypt's need for arms; 2) creating regional stability; 3) improving the political, economic and social situation; 4) creating a favourable image of Egypt in Western eyes; 5) ensuring USA neutrality in relation to any conflict between Egypt and Israel. ${ }^{6}$ The foreign policy problem that required as-Sādāt's immediate attention was the ceasefire with Israel. The Americans withdrew from the Four Power talks, alleging that the USSR was violating its commitments in relation to the ceasefire in the Suez Canal Zone. ${ }^{7}$ They simultaneously accused Egypt of violating the ceasefire and joined Israel in demanding the removal of Egyptian missiles from the Suez Canal front. ${ }^{8}$ On 8 October the Soviet Ministry of Foreign Affairs declared that the US State Department was trying to shift the responsibility for the situation in the Middle East on to the USSR and the Arab countries, stressing that the USSR had not taken part in drafting any of the ceasefire terms which had been put forward by

\footnotetext{
${ }^{2}$ HEIKAL, M. Sphinx and Commissar. The Rise and Fall of Soviet Influence in the Arab World. London: Collins, 1978, p. 216.

${ }^{3}$ Pravda, 4 October 1970.

${ }^{4}$ RUBINSTEIN, A. Z. Red Star on the Nile. The Soviet-Egyptian Influence Relationship since the June War, p. 130.

${ }^{5}$ HAYKAL, Muhammad Hasanayn. Aț-țarīq ilā ramaḍān [The Road to Ramadan], p. 110.

${ }^{6}$ El-HUSSINI, Mohrez Mahmoud. Soviet-Egyptian Relations, 1945 - 85, pp. 191-192

${ }^{7}$ KISSINGER, H. The White House Years, p. 591.

${ }^{8}$ SELLA, A. Soviet Political and Military Conduct in the Middle East, pp. 28-29.
} 
the US government. It also denied that Soviet personnel were manning Egyptian missile sites in the Canal area. ${ }^{9}$

Already on 30 September Anwar as-Sādāt had called for a meeting of the Egyptian Defence Council, which recommended the renewal of the ninety-day ceasefire, which would end on 7 November 1970, for a further period of three months. ${ }^{10}$ So Maḥmūd Riyāḍ, the Egyptian Minister of Foreign Affairs, travelled to New York for a rebuttal of the false accusations at the session of the UN General Assembly. The dispute there ended on 4 November when the General Assembly voted by 57 to 16 in favour of a three-month extension of the ceasefire and the resumption of the Jarring mission on the basis of Resolution 242 and respect for Palestinian rights, most of the Arab states voting in favour, and Israel and the United States being among the opponents. ${ }^{11}$ The resolution condemned the continued Israeli occupation of Arab territories since 5 June 1967, confirmed the inadmissibility of occupying territories by force and the necessity of relinquishing them, and recognition of the rights of the Palestinian people as indispensable for the establishment of a durable and just peace. In this way the international community had decreed that it was not the movement of its missiles by Egypt that was the obstacle to peace; the real obstacle was the delaying and obstructing tactics of Israel. ${ }^{12}$

The United States since the June war had become an open and reliable ally of Israel, providing political backing and military and economic support. It poured all kinds of weapons into Israel at a rate which would ensure its uninterrupted military superiority over the Arabs as a whole. The Soviet Union, on the other hand, was providing the kind of military support to Egypt and Syria which precluded any advantage over Israel, claiming that it did not want an arms race in the Middle East. In this way, the superpowers promoted their own interests in the region within the framework of a mutual understanding. In addition to commanding military superiority, Israeli forces had in the June war reached the Suez Canal in the south, the Jordan River in the East, and occupied the Syrian Golan Heights in the north, all of which were natural obstacles and

\footnotetext{
${ }^{9}$ OSIPOV, A. Y. SShA i arabskie strany, 70-e - nachalo 80-ch godov [The USA and the Arab Countries, 1970s and the beginning of 1980s], p. 34.

${ }^{10}$ RIYĀḌ, M. Mudakkirāt Maḥmūd Riyāḍ (1948 - 1978). Vol. I. Al-baḥt an as-salām .. wa aș-șirāc fi ash-sharq al-awsat [Memoirs of Maḥmūd Riyāḍ. The Search for peace ... and the struggle in the Middle East], p. 318.

${ }^{11}$ General Assembly resolution 2628 (XXV), 4 November 1970. Quoted in BAILEY, S. D. Four Arab-Israeli Wars and the Peace Process. London: Macmillan, 1990, pp. 290-291.

${ }^{12}$ RIYĀḌ, M. Mudakkirāt Maḥmūd Riyāẹ (1948 - 1978). Vol. I, p. 322.
} 
barriers. ${ }^{13}$ Consequently, these lines had become Israel's most effective strategic positions.

In the Egyptian army command it was clear that after the victorious June war, the Israeli leadership had decided on a strategy to force Arab will to yield to its own, so that peace could be imposed under its conditions. This meant that Israel had to maintain military superiority to be able to impose the fait accompli in the occupied territories, and to prevent the Arabs from considering an all-out war by instilling in them a feeling of futility, inadequacy and despair. ${ }^{14}$ In this oppressive atmosphere President Jamāl ${ }^{\mathrm{c}}$ Abdannāșir endorsed a new strategy: "We lost a battle but we did not lose the war. We will not surrender. The war has not ended, it is going on. Our will is not broken". 15

The Egyptian armed forces were considered the main threat and Israel therefore concentrated on Sinai, erecting fortifications and defence lines, building airports and roads, and stationing seasoned men backed by armoured units to confront any eventual Egyptian attack. The assumption was that it would be difficult, if not impossible, for large numbers of Egyptian forces to cross the Suez Canal - a daunting and unique obstacle - and then have to face strong resistance from Israeli forces. In the estimation of the Israeli Chief of General Staff, General David Elazar, if the Egyptians did take this risk, the Canal would be their graveyard. Previous experience had taught the Israelis, as it had taught the Egyptians, that in a war no military cooperation was likely between Arab countries. ${ }^{16}$ Israel could therefore afford to isolate each front and deal with it separately. And as long as Egypt was unable to carry out an all-out attack then other Arab countries would not fight. In conclusion, Israel thought it could impose a fait accompli by force to make the Arabs surrender. This state of affairs suited the United States in its regional policy against the Soviet Union.

Anwar as-Sādāt established a general set of priorities and guidelines for Egypt's foreign policy. Some reflected a continuation of Jamāl cAbdannāṣir's strategy, others represented new approaches. Generally, the foreign policy of Anwar as-Sādāt towards the USA was a continuation of the strategy of his predecessor: both inclined towards a positive response to the American initiative, as expressed in the Rogers' plan, on 8 August 1970. ${ }^{17}$ Jamāl 'Abdannāșir's move can be seen as a desperate decision aimed at putting pressure on both the USA and the USSR to re-examine their policies towards

\footnotetext{
${ }^{13}$ BAILEY, S. D. Four Arab-Israeli Wars and the Peace Process, p. 240.

${ }^{14}$ El-GAMASY, M. A. G. The October War. Memoirs of Field Marshal el-Gamasy of Egypt, p. 128.

${ }^{15}$ HUWAYDĪ, A. Hurūb c Abdinnāṣiri ['Adannāṣir's wars], p. 146.

${ }^{16}$ El-GAMASY, M. A. G. The October War, p. 129.

${ }^{17}$ KISSINGER, H. The White House Years, pp. 374-375.
} 
Egypt. Anwar as-Sādāt's initiative can be considered as a deliberate move to establish a new basis for American-Egyptian relations. His initiative corresponded to several changes in the foundations of US foreign policy and also presented new responses to longstanding differences between the two countries. Anwar as-Sādāt must have recognized that the interests of the USA and Israel were closely linked, so he sought to expose the gaps between their respective interests and policies in order to put pressure on Israel. ${ }^{18}$ Egypt's primary foreign policy challenge was the stalemate along the Suez Canal. Despite the ceasefire standstill agreement, the Israelis seemed intent on settling in for a long stay in the Sinai. As early as October 1967, they began developing plans to establish settlements there. Israel's effort to establish a seemingly permanent presence in the Sinai only reinforced Egypt's apparent impotence in the face of Israeli power. ${ }^{19}$

Anwar as-Sādāt was fully aware of the changing pattern of US foreign policy during the era of Richard Nixon and Henry Kissinger in comparison with the President Lyndon Johnson administration. President Nixon, in his inaugural address of January 1969, committed the USA to an enduring peace. In his foreign policy report to Congress in early 1970, the president explained his new strategy. He insisted that attainment of a lasting peace called for a foreign policy guided by three basic principles: strength, partnership and willingness to negotiate: "Peace must provide a durable structure of international relationship which inhibits or removes the causes of war ... a partnership in which the US cannot and will not undertake all the defence of the free nations of the world". ${ }^{20}$ While Anwar as-Sādāt was still feeling his way forward he had really no alternative except to continue preparations for the next round of fighting, but to treat with all seriousness the search for a peaceful settlement. ${ }^{21}$

Anwar as-Sādāt's calculations were a response to Nixon's perception of the nature of the communism who warned against the communist threat. He realised that a long period of post-war international relations had now ended. The rules of the game that had been applicable to the bipolar world of the previous decades could no longer guide policy-makers in the future. With this in mind, the new elements in his policy towards the USA become clearer. On 23 November 1970, Anwar as-Sādāt sent Richard Nixon a further letter, delivered only on 14 December, revealing Egypt's interest in Jarring's initiative and in

\footnotetext{
${ }^{18}$ El-HUSSINI, M. M. Soviet-Egyptian Relations, 1945 - 1985, p. 192.

${ }^{19}$ COOK, S. A. The Struggle for Egypt. From Nasser to Tahrir Square, pp. 118-119.

${ }^{20}$ NIXON, R. "A Report to the Congress”, 18 February 1970, pp. 1-13.

${ }^{21}$ HEIKAL, M. Sphinx and Commissar, p. 219.
} 
peace. ${ }^{22}$ In his reply of 22 December, sent via Prime Minister Maḥmūd Fawzī, Richard Nixon praised this new line of thought and asked for further cooperation and mutual confidence. ${ }^{23}$ In his answering letter to Richard Nixon Anwar as-Sādāt indicated the new basis of Egypt's foreign policy, in which he declared that Egypt no longer existed inside the Soviet sphere of influence, and that Egyptian decisions would henceforth be independent of external influence or tutelage, and in consequence any contacts between Egypt and the USA should be directly conducted between Cairo and Washington. ${ }^{24}$ Nixon's answer came within two days and was very friendly.

From a military perspective, Soviet military presence and influence in the region constituted a direct threat to American national interests and objectives. Access to naval and air facilities in Egypt allowed the Soviet Fifth Eskadra to deny the free use of the Mediterranean region to the US Sixth Fleet, and to outflank the southern front of NATO ${ }^{25}$ More importantly, the permanent Soviet naval presence enabled their sea power to function as an effective diplomatic instrument in Soviet political initiatives in the region. According to Anwar asSādāt, the reconnaissance TU-16 and the electronic surveillance AN-12 planes were used in operations over the Mediterranean, where their activity was often directed at the US Sixth Fleet. ${ }^{26}$

In contrast with the signs of understanding between Cairo and Washington, Soviet-Egyptian relations had their difficulties. Preparations for a new armed conflict had been curtailed by the Soviet reluctance to answer the president's repeated appeals for supplies of the types of arms which could make an Egyptian crossing of the Suez Canal a feasible alternative to his diplomatic initiatives. He specifically required fighter bombers capable matching the Phantoms possessed by Israel. ${ }^{27}$ The Soviet Union looked suspiciously at the new Egyptian leadership. They were annoyed at Anwar as-Sādāt's increasing contacts with Saudi Arabia and the signs of an emerging understanding between Cairo and Washington - particularly the active role of the latter in the negotiations for a Middle East settlement. ${ }^{28}$ In addition, there was his choice of the moderate Mahmūd Fawzī as Prime Minister, rather than one of the

\footnotetext{
${ }^{22}$ As-SĀDĀT, Anwar. Baht $\underline{~}^{c}$ an ad $\underline{d}$ - $\underline{d} \bar{t} t$. Qișsat hayātī [In Search of Identity. The Story of My Life], p. 234.

${ }^{23}$ QUANDT, W. B. Decade of Decisions. American Policy Toward the Arab-Israeli Conflict, 1967 - 1976, p. 133.

${ }^{24}$ As-SĀDĀT, A. Baht $\underline{t}^{c}$ an ad- $\underline{d} \bar{a} t$, p. 288.

${ }^{25}$ SELLA, A. Soviet Political and Military Conduct in the Middle East, p. 31.

${ }^{26}$ As-SĀDĀT, A. Baht ${ }^{c}$ an ad-dāt, p. 234.

${ }^{27}$ El-HUSSINI, Mohrez Mahmoud. Soviet-Egyptian Relations, 1945 - 85, p. 194.

${ }^{28}$ HEIKAL, M. Sphinx and Commissar, p. 219.
} 
"lieutenants" of the deceased president, such as the Vice-President cAlī Șabrī, or the Minister of the Interior and Secretary General of the Arab Socialist Union (ASU) Sha ${ }^{\mathrm{c}}$ rawī Jumª. ${ }^{29}$

The Egyptian party and government delegation to Moscow from 20 to 25 December 1970 was led by Vice President ${ }^{\mathrm{c}} \mathrm{Al} \overline{1}$ Șabrī and its members were Minister of Foreign Affairs Maḥmūd Riyāḍ, Minister of Industry Dr. ${ }^{\mathrm{c} A z \bar{z} z}$ Șidq̄i and Minister of Defence Colonel General Muhammad Fawzī. ${ }^{30}$ Amid reports that the USSR had increased its staff in Egypt to nearly 20,000 and that the secretary of the CPSU Central Committee, Boris Nikolayevich Ponomaryov, had promised Egypt full Soviet support during a visit to Cairo in early December, ${ }^{31}$ the Kremlin negotiations became particularly important. There were three meetings with the Soviet leadership, led by Leonid Ilyich Brezhnev.

On the morning of 21 December 1970, the delegation was received by Leonid Brezhnev in the presence of Nikolay Viktorovich Podgorniy, Alexey Nikolayevich Kosygin, Andrey Andreyevich Gromyko and Marshal Andrey Antonovich Grechko. Alexey Kosygin in a welcome speech noted among other things that the Middle East had become one of the most dangerous flashpoints for future war in the world. The Egyptians reminded the Soviets that the USA aimed to expel the USSR from the region and blackmail states that refused to accept Israeli conditions and wanted to cooperate militarily between themselves. ${ }^{c}$ Ali Sabrī recalled the collapse of the US peace initiative and criticized the escalating US efforts to achieve a permanent ceasefire in the current context of ever-increasing diplomatic, military and political support for Israel. This was forcing Egypt to strengthen its political, military and economic relations with the USSR. Mạ̣mūd Riyād criticized Henry Kissinger's statements about the need to push the USSR out of the Middle East and that Egypt should not emerge stronger from the clash with Israel. ${ }^{32}$ The United States simply wanted to prevent Egypt from gaining the upper hand in the conflict with Israel. He stressed that the failure of the Rogers plan stemmed from Israel's stance, which it did not intend to withdraw until it was militarily pushed out. The domestic press reported that the talks had begun on 21 December and published texts by Alexey Kosygin and ${ }^{\mathrm{c}}$ Alī Sabrī. ${ }^{33}$

${ }^{29}$ IMĀM, 'Abdallāh. Inqilāb 15 māyū. Al-qișşa al-kāmila [The Coup of 15 May. The Full Story], pp. 127-128.

${ }^{30}$ Al-Ahrām, 20 December 1970.

${ }^{31}$ The Times (London), 17 December 1970. Quoted in RUBINSTEIN, A. Z. Red Star on the Nile, p. 133.

32 RIYĀḌ, M. Mudakkirāt Mahmmūd Riyāẹ (1948 - 1978), Vol. I, p. 328.

${ }^{33}$ Pravda, 22 December 1970. 
There was also a bilateral meeting between the Egyptian delegation and Marshal Grechko, who wanted to be acquainted with the Egyptian delegation's views on strengthening political, economic and military ties with the USSR, especially after the change in US policy towards Israel and their support for a permanent ceasefire in the region. As the United States decided in 1971 to support Israel with a new loan for arms acquisition to restore military balance, the Egyptian delegation focused on acquiring the TU-16 missile-armed fighterbombers with which the Soviet leadership had intended to support the Egyptian armed forces. ${ }^{34}$

After several rounds of bilateral talks between foreign and defence ministers, Soviet officials did not take a position until on 25 December. Leonid Brezhnev stated that Israel had refused to implement the United Nations Security Resolution 242 and the US supported it in this position, so the world could see who was rejecting peace. "Egypt has 750,000 men in arms, so it must explore all options to choose the most appropriate way out. There are about 6 weeks until the end of the current ceasefire, and it is clear that, given the domestic situation, it is difficult for Egypt to agree to extend the ceasefire. Egypt has proposed the use of troops from the four powers at the borders as a guarantee for peace, which is essentially a peace initiative, so that Israel, which claims it needs protection, will hardly be able to reject it. If the Americans agree, Israel will certainly obey, Brezhnev continued. If the proposal is rejected, the world will be even more aware of Israel's expansionist plans. In this matter, the USSR wants to join forces with the French and the British so that Gunnar Jarring can resume his mission, because the draft of the BR resolution threatening Israel with sanctions will be vetoed by the USA. Egypt seems to need to consider a third extension of the ceasefire and adopt a flexible policy. You do not have to say that you will resume fighting, especially in the light of the previous UNSC resolutions on the need for Israel to withdraw; you still have time for political action, but we advise you not to announce what you want to do after 5 February, when the second armistice ends. In any case, you must work to strengthen the Egyptian army, become familiar with the use of modern weapons and intensify the training of your pilots. We will provide you with comprehensive assistance in this regard. As for a full military confrontation with Israel, we cannot take that away from you. It's a thing that needs scrutiny until you get a $200 \%$

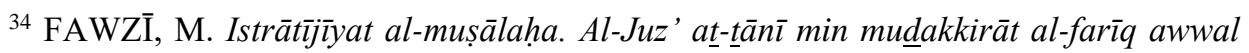
Muhammad Fawzī [Strategy of Conciliation. Part II of Memoirs of Colonel General Muḥammad Fawzī], p. 150.
} 
confidence about your success. Artillery fire over the canal is one thing, but a frontal attack is another". 35

The Soviet leaders swiftly complied with Egyptian military demands. They sent a timetable with the delivery dates of armaments and materials, in which they focused on adjusting the quantities of ammunition and spare missiles for storage in Egypt. They also sent a technical group to make sure of the correct location of the equipment, instruments and devices of the heavy rocket brigade at two airports in Upper Egypt before their installation. When the Egyptian delegation submitted a new plan for repaying Egypt's debt to the Soviet Union, Brezhnev agreed to provide economic assistance and ensured deferment of the instalments. ${ }^{36}$

To sum up the attitudes of the superpowers, the USSR was willing to provide all-round military assistance to Egypt and postpone deferment of the instalments, with the exception of deliveries of TU-16 missile-armed fighterbombers. Soviet officials argued that Egypt should not engage in all-out war to liberate its occupied territories. They preferred to extend the ceasefire, during which time Egypt would continue its intense political activity, despite Israel slamming the door on the dialogue. It is clear that the USSR preferred a peaceful solution, and should Egypt decide to resume combat operations, the USSR did not want to participate in this solution. The decision to fight had to be exclusively Egyptian. ${ }^{37}$ Brezhnev confirmed in his speech the consent of the USSR to the political, military and economic support of the people and government of Egypt. However, he did not give up hope that the second truce would be used to put political pressure on the United States and the great powers, with the USSR making every effort to do so. The visit was considered a success in Moscow: it confirmed the current commitments, reassured the Soviet leadership of the continuity of Egyptian politics and paved the way for Nikolay Podgorniy's visit. $^{38}$ At that time, the secret contacts of Anwar as-Sādāt, signalling to the Americans that he wanted peace, were not yet known. ${ }^{39}$

Beginning in January 1971 Anwar as-Sādāt sought to get out from under the collective leadership to which he had agreed and therefore simultaneously began to pursue policies independent of the Arab Socialist Union's Supreme

35 Quoted in RIYĀḌ, M. Mudakkirāt Maḥmūd Riyāẹ (1948 - 1978), Vol. I, pp. 328-330.

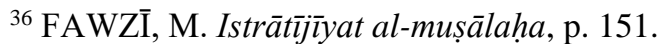

${ }^{37}$ RIYĀḌ, M. Mudakkirāt Mahmūd Riyāẹ (1948 - 1978), Vol. I, p. 331.

${ }^{38}$ GOLAN, G. Soviet Policies in the Middle East. From World War II to Gorbachev, p. 77.

${ }^{39}$ Foreign Broadcast Information Service (FBIS), Washington; USSR, 20 January 1971, pp. A1-A3. Quoted in RUBINSTEIN, A. Z. Red Star on the Nile, p. 135. 
Executive Committee (SEC) ${ }^{40}$ and to cultivate critical constituencies. ${ }^{41}$ The president's most important task was to control the army, so he began cultivating a rung of officers just below Defence Minister Muhammad Fawzī, known for his left-wing sympathies, to win them over. Among these were the CGS Lieutenant General Muḥammad Șādiq, Lieutenant General Sa ${ }^{c}$ daddīn ash-Shāzlī and Major Generals Aḥmad Ismā ${ }^{\mathrm{c}} \overline{1} l{ }^{\mathrm{c}} \mathrm{Al} \overline{1}$ and Muhammad ${ }^{\mathrm{c}}$ Abdalganā alJamasī. ${ }^{42}$ Professional soldiers, angry that they had to face a disunited domestic front in times of war, were willing to support the legitimate power of the Supreme Commander. Dissatisfaction in military circles with the USSR military mission and delayed arms deliveries focused on ${ }^{\mathrm{c}} \mathrm{Al} \overline{1}$ Șabrī for his good contacts with the USSR. Moreover, the conservative views of Anwar as-Sādāt were closer to those of many of the officer elite than left-wing nassirism. The president did not spare any effort even to gain support in other state bodies, such as the police and the secret service. ${ }^{43}$ He had the easiest task with senior government officials, who were angered by leftist attacks on their privileges. After many years of power struggles against politicians with a military background such as ${ }^{c} A 1 \overline{1}$ Șabrī and many others, they welcomed opportunities to rise higher, which the president's victory offered them. In general, Anwar asSādāt benefited from the ambitions of those who felt that the ${ }^{\mathrm{c}}$ Ali Sabrī group was limiting their career progress. Many members of the National Assembly, a long-standing position held by Anwar as-Sādāt and his ally Sayyid $\mathrm{Mar}^{\mathrm{C}} \overline{1},{ }^{44}$ and the bastion of the conservative strata of society, despite the left-wing thinking of its president, Dr. Labīb Shuqayr, quickly moved to the president's side hoping to rid them of social radicalism.

At the beginning of 1971 Anwar as-Sādāt still faced the problem of what to do next as he had not yet resolved on his political course. In order to secure his position he had to decide what to do about the occupied territory of Sinai. No Egyptian leader could reconcile himself to this continued grievance. Soviet political and military intervention on Egypt's side had failed to get Israel to withdraw; now, the Americans were proffering a diplomatic line which might be worth following up for a time, until things fell into shape. It was a slender

\footnotetext{
${ }^{40}$ In Arabic (al-Lajna at-tanfìdīya al- $\left.{ }^{c} u l y a \bar{a}\right)$, there also occurs the translation "Higher executive committee".

${ }^{41}$ COOK, S. A. The Struggle for Egypt. From Nasser to Tahrir Square, p. 119.

${ }^{42}$ In English his name often occurs as "el-Gamasy".

${ }^{43}$ HINNEBUSCH, R. Egyptian Politics under Sadat. The post-populist development of an authoritarian- modernizing state, p. 43.

44 MAZHAR, S. Qișsat aș-șirāc bayna as-Sādāt wa rijāl 'Abdannāșir [Story of the Struggle between as-Sādāt and 'Abdannāṣir's Men], pp. 33-34; MAR cī, Sayyid. Awrāq siyāsìya [Political Papers], Vol. III, pp. 618.
} 
thread, but nothing better offered. ${ }^{45}$ Inside Egypt morale was low, with masses of refugees crowding into Cairo from the Canal cities. High-ranking American officials such as President Nixon and Henry Kissinger made no secret of their desire to get the Soviets out of Egypt and thereby weaken the entire Soviet position in the eastern Mediterranean. Deprived of their air bases in Egypt and lacking aircraft carriers to provide air cover for their eskadra, the Soviets were clearly put at a tactical disadvantage with respect to the US fleet in the Mediterranean, and Anwar as-Sādāt must have assumed that the USA would be grateful for his expulsion of the Soviets. ${ }^{46}$

Nikolay Podgorniy, chairman of the Presidium of the Supreme Soviet, visited Egypt on 13 January 1971 at the head of a large economic and military delegation, to attend the celebrations of the completion of work on the High Dam in Aswan and its ceremonial commissioning. The USSR had invested a lot of material resources and technical effort in building this project, and the result was translated into the strengthening of relations of friendship and cooperation between the USSR and Egypt. ${ }^{47}$ The USSR had reason to be satisfied: it had helped build the largest construction project in the Middle East since the time of the pyramids, its armed forces had gained a valuable basic network and established good relations with the new Egyptian leadership. ${ }^{48}$ On this occasion, Anwar as-Sādāt praised the enormous merits of the USSR in building this huge project. He stressed that the Americans had also undertaken to help build this work, but had cancelled their involvement. The high dam - this work built in cooperation with the USSR - also provided electricity to the entire Egyptian countryside. He also highlighted the huge help the USSR had provided to Egypt during the difficult days of 1967. In a statement on January 19, the Soviet government proudly committed itself to two major economic projects: electrifying rural areas and fertilizing 360,000 hectares of new land with water from a dammed lake. At a summit on 14 January issues related to mutual relations, military and economic assistance to Egypt and the forthcoming resumption of liberation struggles were discussed. ${ }^{49}$ Both parties requested a settlement based on the implementation of UNSCR 242. Anwar as-Sādāt promised to visit the USSR the following month.

Anwar as-Sādāt carefully orchestrated his dealings with all parties to the Middle East conflict and pursued a negotiated agreement through all the

\footnotetext{
${ }^{45}$ SELLA, A. Soviet Political and Military Conduct in the Middle East, p. 31.

${ }^{46}$ FREEDMAN, R. O. Soviet Policy Toward the Middle East Since 1970, p. 88.

${ }^{47}$ HAYKAL, Muhammad Ḥasanayn. Aț-țarīq ilā ramad̄ān, p. 117.

${ }^{48}$ RUBINSTEIN, A. Z. Red Star on the Nile, pp. 135-136.

${ }^{49}$ RIYĀḌ, M. Mudakkirāt Mahmūid Riyād (1948 - 1978). Vol. I, pp. 337-339; FAWZĪ, M. Istrātījūyat al-muṣālaḥa, p. 151.
} 
avenues that became open to him. The first of these was the renewed attempt by UN Special Representative Gunnar Jarring to break the deadlock. The possibility of reopening the Suez Canal had often been discussed since the beginning of 1968 as part of an interim settlement that could lead to a final settlement. The Israeli government's decision of 28 December 1970 to resume indirect negotiations with Egypt through Gunnar Jarring revived hopes for progress on the matter. Israel had reluctantly acknowledged that Egypt would not withdraw any missiles to the pre-August 7 line and had agreed to negotiate with Jarring. ${ }^{50}$ Israeli Foreign Minister Abba Eban commented: "Both Nixon and Rogers are convinced - quite rightly - that Israel should climb down from the triumphalism of the Six-Day War and start working on a strategy of accommodation in the Middle East. According to them, the fighting that could draw the USA into an unwanted confrontation with the USSR must be ended". 51 Although Israeli Prime Minister Golda Meir resisted for several weeks, she had to agree to a truce. ${ }^{52}$

Departing from its stand of early 1968, Israel yielded to a combination of U.S. pressure and the conviction of leaders such as Minister of Defence, Lt. Gen. Moshe Dayan, who believed that diplomacy would prove more conducive than fighting to ending the state of war.. ${ }^{53}$ Most Israeli politicians considered Dayan's views to be inchoate. ${ }^{54}$ Perhaps more important, however, was the impression, given in the Arab world by American declarations of an evenhanded policy in the Middle East, that the United States might be willing to assist the Arab states in regaining at least part, if not all, of the land lost to Israel in 1967 - something the USSR had been unable to do by diplomacy and was still unwilling to do by force. ${ }^{55}$ Following these exchanges, on 4 February 1971 the Egyptian president was fully aware that Israel was negotiating from a position of strength, and thus he expected a rejection of these terms. Nevertheless, he was able to enlist not only the USA but also world opinion on his side. At this point he was also able to pave the way for Richard Nixon to take an active diplomatic role in the search for a settlement. ${ }^{56}$

\footnotetext{
${ }^{50}$ RUBINSTEIN, A. Z. Red Star on the Nile, pp. 136.

${ }^{51}$ EBAN, A. Personal Witness: Israel Through my Eyes, p. 488.

52 TYLER, P. Fortress Israel. The Inside Story of the Military Elite who Run the Country and why they Can't Make Peace, p. 214.

${ }^{53}$ IMĀM, ${ }^{\mathrm{c}}$ Abdallāh. Inqilāb 15 māyū. Al-qișsa al-kāmila, p. 143; RUBINSTEIN, A. Z. Red Star on the Nile, p. 136; FREEDMAN, R. O. Soviet Policy Toward the Middle East Since 1970, p. 41.

54 RAFAEL, G. Destination Peace: Three Decades of Israeli Foreign Policy. A Personal Memoir, pp. 264-266; EBAN, A. An Autobiography, pp. 474-475.

${ }^{55}$ FREEDMAN, R. O. Soviet Policy Toward the Middle East Since 1970, p. 41.

${ }^{56}$ El-HUSSINI, Mohrez Mahmoud. Soviet-Egyptian Relations, 1945 - 1985, p. 194.
} 
On 4 February 1971, Anwar as-Sādāt - after informal talks with Donald Bergus, ${ }^{57}$ - combined the expected announcement of a 30-day ceasefire extension until March 7 with a surprising new initiative. This step was undertaken without any prior discussion with or consent from the collective leadership. ${ }^{58}$ In an address to the National Assembly Anwar as-Sādāt declared that if Israel withdrew its troops from the east bank of the Suez Canal and agreed to implement Resolution 242, Egypt would immediately begin clearing the canal so that it could be reopened again to serve the world. ${ }^{59} \mathrm{He}$ also promised to extend the ceasefire agreement from three to six months to allow Gunnar Jarring to complete a settlement that would allow Israeli ships to sail freely through the canal and to improve diplomatic relations with the United States. ${ }^{60}$ However, the conclusion of a peace treaty, a condition that Israel had consistently put forward to test the goodwill of Egypt, was ruled out. ${ }^{61}$ Most members of the Supreme executive committee of the Arab Socialist Union around ${ }^{\mathrm{C}}$ Ali Șabrī naturally sharply criticized the president's initiative. ${ }^{62}$

Anwar as-Sādāt encountered several obstacles in his diplomatic initiative: his own foreign minister, the Palestinians and the Soviets. Maḥmūd Riyād strongly opposed any interim solution, claiming that it would become an unwanted permanent line of demarcation. ${ }^{63}$ However, the president bypassed him and discussed these tricky issues several times directly with Donald Bergus or through Muhammad Hasanayn Haykal. These soundings, which took place throughout the spring, aroused slight optimism among senior State Department officials, who believed the breakthrough was in sight. The White House was more sceptical, in part because if the USSR was so heavily involved in Egypt, it was less likely to put pressure on Israel. ${ }^{64}$

On 8 February, Gunnar Jarring presented the text of a new initiative, which he sent to Egypt and Israel with a view to seriously implementing Resolution 242. The essence of the initiative was for Israel to express a commitment to withdraw from all occupied territories in 1967 in exchange for Egypt's

\footnotetext{
${ }^{57} \mathrm{He}$ was the head of the U.S. Interests Section at the Spanish Embassy in Cairo.

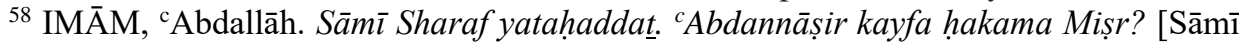
Sharaf speaks. 'Abdannāṣir how did he rule Egypt?], p. 403.

${ }^{59}$ Address to the National Council, 4 February 1971. In ISRAELI, R. The Public Diary of President Sadat. Part One, pp. 30-32; As-SĀDĀT, Anwar. Baht ${ }^{c}$ an ad-dāt. Qișsat hayātī, pp. 289-290.

${ }^{60}$ As-SĀDĀT, Anwar. Baht $\underline{t}^{c}$ an ad-dät, p. 290.

${ }^{61} \mathrm{IMĀM},{ }^{\mathrm{c}} \mathrm{Abdallāh}$. Inqilāb 15 māyū. Al-qișșa al-kāmila, pp. 140-143.

62 HAYKAL, Muḥammad Ḥasanayn. Aț-tarīq ilā ramaḍān, p. 111; MAR $\bar{I}$, Sayyid. Awrāq siyāsīya, Vol. III, p. 639.

${ }^{63}$ RIYĀḌ, M. Mudakkirāt Maḥmūd Riyāẹ (1948 - 1978). Vol. I, p. 343.

${ }^{64}$ RUBINSTEIN, A. Z. Red Star on the Nile, p. 138.
} 
commitment to sign with Israel a peace treaty, end the state of war and recognize Israel's right to exist and the right of every state to live safely within its borders. ${ }^{65}$ However, the initiative did not meet with a positive response, especially in Israel. ${ }^{66}$ Israel's refusal to endorse the Egyptian position that an accord on the Canal be considered a first step in the withdrawal from all the occupied territories prompted the USA to seek a mediator role in talks between Egypt and Israel. However these efforts also failed because of the gap between the two negotiating positions. ${ }^{67}$

The representatives of the USSR had to be approached differently. When Israel was unwilling to withdraw, Anwar as-Sādāt had to reckon with the resumption of fighting, if not immediately after the ceasefire expired then in the foreseeable future. He needed assurances that the USSR would support him, so on 1 March 1971 he flew secretly to Moscow, where he had two days of intensive negotiations. ${ }^{68}$ The Egyptian delegation led by the president, whose members were Minister of the Interior Sha ${ }^{c}$ rāwī Jum ${ }^{c}$ a and Minister of Defence Colonel General Muhammad Fawzī, accompanied by the Soviet ambassador Vladimir Vinogradov and other senior Soviet officials, flew without media attention to visit the USSR. It was joined in Moscow by the Egyptian ambassador, Murād Ġālib. The summit conference took place on 1 and 2 March. It was Anwar as-Sādāt's first visit to the USSR as President of the Republic. ${ }^{69}$ There were three things he wanted to ask for: to arrange a joint military and political strategy, for Egypt to be put on an equal footing with Israel as far as arms went and to secure the current flow of arms deliveries. ${ }^{70}$

The Soviet leaders were cautious about advocating a military solution to the dispute and reluctant to answer Egypt's requests. Anwar as-Sādāt informed them about American efforts to convince him that, "the USSR cannot help Egypt, only the USA can do that and so Egypt has to trust the Americans and to follow their advice". ${ }^{71}$ The visit ended with Brezhnev's promise to send Egypt various kinds of weapons. ${ }^{72}$ It turned out that the Soviet leadership preferred to

${ }^{65}$ RIYĀḌ, M. Mudakkirāt Mahmūid Riyāẹ (1948 - 1978). Vol. I, p. 344.

${ }^{66}$ BAILEY, S. D. Four Arab-Israeli Wars and the Peace Process, p. 291; DAYAN, M. Story of my Life, p. 457.

${ }^{67}$ TAYLOR, A. R. The Arab Balance of Power, p. 50.

${ }^{68}$ HAYKAL, Muhammad Hasanayn. Uktūbar 73. As-silāh wa as-siyāsa [October 73. Weapons and Politics], p. 169;

${ }^{69}$ As-SĀDĀT, A. Baht ${ }^{c}$ an ad-dāt, p. 233; WANNER, J. Krvavý Jom Kippur. Čtvrtá a pátá arabsko-izraelská válka ve světové politice [The Bloody Yom Kippur. The Fourth and Fifth Arab-Israeli Wars in World Politics], p. 86.

${ }^{70}$ HAYKAL, Muhammad Ḥasanayn. At-țarīq ilā ramaḍān, p. 112.

${ }^{71}$ Quoted in HEIKAL, M. Sphinx and Commissar, p. 221.

${ }^{72}$ As-SĀDĀT, A. Baht $\underline{c}^{c}$ an a $\underline{a}-\underline{d} \bar{a} t$, p. 233. 
wait and follow the attitude of the new political leadership and direction in Egypt and its behaviour in the field of international and domestic policy towards the realization of Egypt's strategic goal - elimination of the consequences of war - whether by peace or war. However, the five months that Anwar as-Sādāt spent in the presidency were not enough to reveal his real attitudes towards the Soviet leadership. ${ }^{73}$

Anwar as-Sādāt declared that, "the Soviet presence in the area is in our country's interest ... I know that my real enemy is the US and western imperialism. I am prepared, just as Jamāl ${ }^{\mathrm{c}}$ Abdannāșir was, to face anything in Egypt or in the Arab area, to continue the same task, and in return for Soviet assistance Egypt would afford facilities to the Soviet Union because of their help". ${ }^{74}$ However, if Jamāl "Abdannāṣir had pursued a policy of appeasement, accepting Soviet tutelage as being his only reliable option, Anwar as-Sādāt initiated a policy of compromise with the Soviet Union, using the granting of naval facilities as a bargaining counter in future negotiations with Moscow. This was consistent with the course of the negotiations during this visit. His main objective was to convince the Soviets that they should deliver offensive weapons to Egypt, both to deter Israel from threatening vital objectives inside Egypt, and to help fulfil his promise that 1971 would be the year of decision in the Arab-Israeli dispute. ${ }^{75}$

At this meeting, Anwar as-Sādāt focused on obtaining further military assistance: mainly weapons and modern technical equipment. He recalled in particular the "deterrent weapon", which he understood as missile-armed longrange fighter bombers. The president was of the opinion that the specification of supplies and their scope must come more often than in the previous period, because if the peaceful solution failed - the president hinted at his initiative on 4 February - Egypt must be ready to start the liberation struggle. The first meeting, during which the president talked about the demands and set out Egypt's position, and Soviet leaders asked for additional explanations concerning his peace initiative, took three hours. The second meeting began with the Soviet promise to deliver military aid, which had already been discussed at a meeting in December 1970, and some of which had already been delivered to Egypt. Leonid Brezhnev read out the decision of the Soviet leadership with all its details. As Brezhnev was speaking of the concentration of long-range missile-armed fighter bombers in Egypt on the condition that they would be under the command of the chief of the Soviet advisers in Egypt, Anwar as-Sādāt cut him short saying that he could not accept that. "Suppose the

\footnotetext{
${ }^{73}$ FAWZĪ, M. Istrātījūyat al-muṣālaḥa, p. 155.

${ }^{74}$ HEIKAL, M. Sphinx and Commissar, p. 222.

${ }^{75}$ El-HUSSINI, Mohrez Mahmoud. Soviet-Egyptian Relations, 1945 - 1985, p. 195.
} 
Israelis bomb deep inside Egypt again. Am I supposed - as the head of an independent country - to wait for permission from Moscow before I retaliate?",76

Leonid Brezhnev interrupted the reading of the rest of the speech, and the meeting turned into a sharp exchange, first between as-Sādāt and Brezhnev, then as-Sādāt and Kosygin, ${ }^{77}$ and finally between as-Sādāt and Grechko, so that the atmosphere in the hall reached freezing point. Brezhnev did not finish the presentation of the rest of the approved report on new arms deliveries for Egypt. The members of both delegations left the hall and went to the cloakroom to put on their coats before leaving the Kremlin for the airport. Here, as-Sādāt asked Brezhnev not to deploy the aircraft in the UAR, to which he received the answer: "as you wish". ${ }^{78}$ Brezhnev immediately informed his colleagues Kosygin, Podgorniy and Grechko about president's request. Grechko promptly called the Soviet ambassador and the chief of the Soviet advisers and repeated to them the last decision of al-Sādāt to refuse the deployment of fighter bombers in Egypt. 79

Members of both delegations left the Kremlin directly for the airport. During the official farewell ceremony, Marshal Grechko came to General Fawzī with an interpreter and informed him how Anwar as-Sādāt had decided on the aircraft in an interview with Brezhnev in the cloakroom. During the return flight, Muhammad Fawzi asked the Soviet ambassador and the head of the Soviet advisers about the event that took place in the cloakroom and about the words interpreted by Marshal Grechko. Both confirmed to him what had happened between al-Sādāt and Brezhnev, ending the Egyptian-Soviet summit with the deplorable outcome of an adverse effect on relations and the expected resumption of fighting. The Soviet side called the meeting in Moscow a meeting of loss of confidence and scepticism. ${ }^{80}$

At the first meeting with the president after their return, Muhammad Fawzī expressed his displeasure at what had happened in Moscow. Anwar as-Sādāt reassured him not to be annoyed, that it was just a way of putting pressure on the USSR. General Fawzī informed the president that he had obtained all the decisions approved by the Soviet leadership, which Brezhnev had not finished reading out at the meeting on 2 March: the USSR would supply everything Egypt asked for with the exception of missile-armed fighter-bombers. ${ }^{81}$ When

\footnotetext{
${ }^{76}$ Quoted in HAYKAL, Muhammad Hasanayn. At-ṭarīq ilā ramad̄ān, p. 112.

${ }^{77}$ As-SĀDĀT, A. Baht ${ }^{c}$ an ad-dāt, p. 233.

${ }^{78}$ FAWZĪ, M. Istrātījūyat al-muṣālaha, p. 152.

${ }^{79}$ FINKLESTONE, Joseph. Anwar Sadat. Visionary who Dared, p. 71.

${ }^{80}$ FAWZĪ, M. Istrātījūyat al-muṣālaha, p. 153.

${ }^{81}$ ISRAELI, R. Man of Defiance. A Political Biography of Anwar Sadat, p. 67.
} 
he subsequently asked the president as commander-in-chief of the army for instructions to begin preparations for the liberation struggle - given that the 7 March, the date of the end of the ceasefire, was approaching - he received the answer that at the next meeting he would be given instructions and a timetable for preparing for the fight. ${ }^{82}$

The news of this dramatic event - the president's refusal to allow the deployment of missile-armed fighter bombers in Egypt - spread in leading government and military circles, and - given the impending resumption of fighting - was met with disapproval. In parallel with this diplomatic initiative, Anwar as-Sādāt continued preparations for what seemed the probable alternative, a further round of going to war with Israel. On 25 March 1971, he addressed a meeting of top commanders of the armed forces and senior Soviet experts, including the head of the Soviet military mission, General Vasiliy Okunev in the Ministry of War, declaring that "once again the destiny of Egypt is in your hands, and all should be prepared for action at any time". ${ }^{83}$ This objective constituted one of the most influential factors affecting the evolution of Soviet-Egyptian relations, particularly during the following period. ${ }^{84}$

When, at the meeting on 1 March, Anwar as-Sādāt indicated his intention to go to war, the Soviet leadership came to his aid and, knowing of his peace offer a month before when he expressed his willingness to embark on a peaceful settlement and avoid war, agreed to deploy fighter bombers in Egypt under a previously concluded agreement. He did not expect the Soviet leadership to agree to position the planes in Egypt so soon, as this would hasten the army's readiness to fight and call into question its claim that Egypt had not yet received the required weapons. He was surprised enough that he failed to control himself and protested directly in the conference room against the way in which the operations of these aircraft would be managed and coordinated. However, with insincere arguments, he revealed to the Soviet leadership his thinking and manoeuvres. ${ }^{85}$

This unpleasant surprise, as a result of which Egypt lost supplies of fighterbombers, affected the date for the start of the liberation struggle, which was about to begin. From the beginning, Anwar as-Sādāt did not understand the depth of the relationship between Egypt and the USSR. He did not understand the strategic overview of Jamāl ${ }^{c}$ Abdannāșir, who was able to obtain enormous Soviet military and political assistance - in a delivery agreed in January 1970, which arrived in Egypt in February and March - and had no idea of the nature

\footnotetext{
${ }^{82}$ FAWZĪ, Muḥammad. Istrātījīyat al-mușālaḥa, p. 153.

${ }^{83}$ HAYKAL, Muhammad Hasanayn. Att-țarīq ilā ramaḍān, p. 113.

${ }^{84}$ El-HUSSINI, Mohrez Mahmoud. Soviet-Egyptian Relations, 1945 - 1985, p. 194.

${ }^{85}$ FAWZĪ, M. Istrātījīyat al-mușālaha, p. 155.
} 
and size of this support, which greatly increased the capabilities of air defence units and air force throughout whole year in preparation for combat. ${ }^{86}$

Muhammad Fawzī doubted that this summit would fulfil hopes of restoring the respect and esteem of the Egyptian armed forces, which had already reached a state of full combat readiness with Israel. However, he did not doubt for a moment that when Egypt decided to go to war the USSR would send the promised air brigade 6 hours after the request. He recalled the words of Jamāl ${ }^{c}$ Abdannāșir of 16 July 1970 in the Kremlin before the Soviet leadership and several marshals: "This time I will not accept defeat - if that happens, you too will suffer damage. You have trained and armed, so there are no excuses. We are fighting imperialism with you and the cooperation and friendship between us has reached its peak". ${ }^{87}$

The Israeli government replied cautiously that it did not intend to withdraw behind the 4 June 1967 line, but asked for clarification on the issue of borders and refugees. ${ }^{88}$ It wanted to keep Sharm ash-Shaykh with the offer to rent it from the Egyptians, and it wanted to address the issue of withdrawal from the occupied Egyptian territories separately from withdrawal from the rest of the occupied Arab territories. The Golan Heights, parts of the West Bank and Jerusalem were not to be discussed; they were to remain under the administration of Israel. Anwar as-Sādāt's initiative led William Rogers to recall - as in December 1969 - that it was stated in the Middle East settlement that Israel withdraw from all occupied territories except minor border adjustments. ${ }^{89}$ Rogers said that guarantees of Israeli security did not necessarily require the acquisition of territory and that demilitarization, and international guarantees, including an international peacekeeping force, would provide the greatest possible security for the parties. ${ }^{90}$ The Israeli government bitterly rejected Rogers' scheme for a settlement founded on international guarantees. Prime Minister Golda Meir commented: "We cannot trust Rogers' offer, even if it is proposed in good faith... There are certain things beyond which our American friends have to realize we will not go". ${ }^{91}$ Thus, Anwar as-Sādāt's initiative of 4 February could be seen not only as a tactical step to strengthen

\footnotetext{
${ }^{86}$ FAWZ̄̄, M. Istrātījīyat al-mușālaha, p. 155.

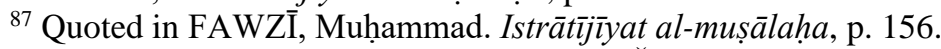

${ }^{88}$ TYLER, P. Fortress Israel, p. 220; BROŽ, I. Arabsko-izraelské války, 1948 - 1973 [The Arab-Israeli Wars], p. 252.

${ }^{89}$ RUBINSTEIN, A. Z. Red Star on the Nile, p. 137.

${ }^{90}$ New York Times, 17 March 1971. Quoted in RUBINSTEIN, A. Z. Red Star on the Nile, p. 142.

${ }^{91}$ New York Times, 18 March 1971. Quoted in RUBINSTEIN, A. Z. Red Star on the Nile, p. 143.
} 
American pressure on Israel, but also as a call for the normalization of relations with Washington and a possible reassessment of relations with Moscow. ${ }^{92}$

Anwar as-Sādāt - because his February initiative elicited no strongly positive response from either the Israelis or the Americans - decided on 6 March 1971 not to renew the ceasefire: the position of "no war, no peace" with Israel was resumed. ${ }^{93}$ During March other occasions of friction with the Soviets had arisen. On 25 March the president addressed a meeting in the Ministry of Defence attended by top commanders of the armed forces and senior Soviet experts saying that the destiny of Egypt was once again in their hands and all should be prepared for action at any time. Some officers complained about the lack of effectiveness of Soviet arms and about delays in supplying them. General Okunev, head of the Soviet Military Mission, was upset but Anwar asSādāt calmed him down by saying that they were not criticizing the Soviet Union. Nevertheless, the Soviets became suspicious of the new Egyptian leadership. ${ }^{94}$ Another incident created still more misunderstanding. Soviet suspicions were increased by the unfortunate and probably deliberate leak in Washington of a remark Anwar as-Sādāt had made to Kamāl Adham. ${ }^{95}$ In a conversation Adham had spoken of American fears over the continuing Soviet presence in Egypt. The president had explained the necessity for this, but added that after the first phase of an Israeli withdrawal had been completed he would undertake to get the Soviets out. This was leaked by Senator Jackson, an ardent supporter of Israel, with the aim of causing trouble to both the USSR and Egypt. $^{96}$

The February initiative of Anwar as-Sādāt brought Jarring's second attempt at promoting a peaceful settlement of the conflict to an unsuccessful conclusion; it earned for Egypt the reputation of having a sincere interest in peace. In response to these developments the Americans took the initiative and tried to promote a limited Egyptian-Israeli understanding that would eventually lead to a broader agreement. By virtue of Washington's favourable attitude toward Egypt's terms for reopening the Canal, Anwar as-Sādāt seemed within reach of a palpable breakthrough with the United States. A visit by Undersecretary of

92 KNYAZEV, A. G. Egipet posle Nasera, 1970 - 1980 [Egypt after Nasser, 1970 1980], p. 30.

${ }^{93}$ BEATTIE, K. J. Egypt during the Sadat Years, p. 58.

${ }^{94}$ HAYKAL, Muḥammad Ḥasanayn. Aț-ṭarìq ilā ramaḍān, p. 113.

${ }^{95}$ Kamāl Adham was counsellor to King Fayșal of Saudi Arabia and head of the Saudi Intelligence service.

${ }^{96}$ HEIKAL, M. Sphinx and Commissar, p. 226. 
State Joseph Sisco to Cairo in late March, had proved promising enough for William Rogers to plan a meeting with Anwar as-Sādāt in early May. ${ }^{97}$

William Rogers arrived on 4 May. In regard of as-Sādāt's initiative he said that the US believed that the present atmosphere was more conducive to a settlement than before, but the Soviet presence in Egypt was a complicating factor. ${ }^{98}$ Rogers' following visit to Israel was utterly ineffective. Because of the gap between the two negotiating positions he was not able to convince the Israelis to accept a comprehensive solution on all fronts. ${ }^{99}$ Soon it became evident that the United States had succumbed to the political pressure being applied by the Jewish lobby, which was demonstrated by the substantial increase in American military and economic aid to Israel. ${ }^{100}$ The USSR remained for Egypt the only faithful supporter.

In the middle of May Anwar as-Sādāt launched a pre-emptive purge against other top members of the "collective leadership" and so he eliminated his most powerful rivals from the political scene. Moscow's response was virtual silence, presumably due to uncertainty about the implications of the "coup" and the president's future course of action. However, it gave rise in Moscow to an unprecedented initiative. On 26 May Nikolay Podgorniy arrived in Cairo at the head of a large delegation, ${ }^{101}$ dispatched for the negotiation and signing of a Treaty of Friendship and Cooperation with Egypt. ${ }^{102}$ The treaty was signed on 27 May and ratified by Egypt on 14 June and by the Soviet Union on 18 June 1971. To the Soviets the treaty was thought to safeguard Moscow's massive stake in Egypt. It was envisaged as a demonstration that the USA had failed in its attempt to drive a wedge between Egypt and the USSR. For Anwar as-Sādāt it was to exert political and psychological pressure on the USA and Israel. More importantly, he viewed it as an official Soviet commitment to deliver the weapons needed for defending Egypt and crossing the Canal.

\footnotetext{
${ }^{97}$ RUBINSTEIN, A. Z. Red Star on the Nile, p. 143.

${ }^{98}$ RIYĀḌ, M. Mudakkirāt Mahmūd Riyāẹ (1948 - 1978), Vol. I, p. 365.

${ }^{99}$ TAYLOR, A. R. The Arab Balance of Power, p. 50.

100 KHOURI, F. The Arab-Israeli Dilemma. New York: Syracuse University Press, 1976, p. 367.

101 The members were: Foreign Minister Andrey Gromyko, General Ivan Pavlovskiy Deputy Defence Minister, and Boris Ponomaryov CPSU Secretary, see in RUBINSTEIN, A. Z. Red Star on the Nile, p 149.

102 RIYĀḌ, Maḥmūd. Mudakkirāt Maḥmūd Riyāẹ (1948 - 1978). Vol. I, p. 374-376.
} 


\section{REFERENCES}

BAILEY, Sydney D. Four Arab-Israeli Wars and the Peace Process. London: Macmillan, 1990.

COOK, Steven A. The Struggle for Egypt. From Nasser to Tahrir Square. New York: Oxford University Press, 2013.

DAYAN, Moshe. Story of my Life. London: Sphere Books, Ltd., 1978.

EBAN, Abba. An Autobiography. London: Weidenfeld and Nicolson, 1978.

EBAN, Abba. Personal Witness: Israel Through my Eyes. New York: Putnam, 1992.

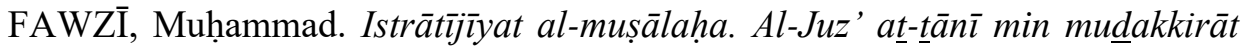
al-farīq awwal Muhammad Fawzī [Strategy of Conciliation. Part II of Memoirs of Colonel General Muḥammad Fawzī]. Cairo: Dār al-mustaqbal al- ${ }^{\mathrm{c}}$ arabīi, 1986.

FREEDMAN, Robert O. Soviet Policy Toward the Middle East Since 1970. New York: Praeger, 1982.

El-GAMASY, Mohamed Abdel Ghani. The October War. Memoirs of Field Marshal el-Gamasy of Egypt. Cairo: The American University in Cairo Press, 1993.

GOLAN, Galia. Soviet Policies in the Middle East. From World War II to Gorbachev. Cambridge University Press, 1990.

HAYKAL, Muhammad Ḥasanayn. Aț-tarìq ilā ramaḍān [The Road to Ramadan]. Beirut: Dār an-nahār li-n-nashr, 1975.

HAYKAL, Muḥammad Ḥasanayn. Uktūbar 73. As-silāh wa as-siyāsa [October 73. Weapons and Politics]. Cairo: Markaz al-Ahrām li-t-tarjama wa-n-nashr, 1993.

HEIKAL, Mohamed. Sphinx and Commissar. The Rise and Fall of Soviet Influence in the Arab World. London: Collins, 1978.

HINNEBUSCH, Raymond. Egyptian Politics under Sadat. The post-populist development of an authoritarian- modernizing state. Cambridge: Cambridge University Press, 1985.

El-HUSSINI, Mohrez Mahmoud. Soviet-Egyptian Relations, 1945 - 1985. London: Macmillan Press, 1987.

HUWAYDĪ, Amīn. Hurūb ${ }^{c}$ Abdinnāsșiri ['Abdannāșiris's wars]. Cairo: Dār almawqif al- ${ }^{\mathrm{c}}$ arabī, 1982.

IMĀM, 'A Abdallāh. Inqilāb 15 māyū. Al-qișșa al-kāmila [The Coup of 15 May. The Full Story]. Cairo: Dār al-mawqif al- ${ }^{\mathrm{c}}$ arabī, 1983.

IMĀM, 'Abdallāh. Sāmī Sharaf yatahaddat. ${ }^{~}$ Abdannāșir kayfa hakama Miṣr? [Sāmī Sharaf speaks. ${ }^{\mathrm{C}}$ Abdannāșir how did he rule Egypt?]. Cairo: Maktabat Madbūlī aṣ-ṣagīìr, 1996. 
ISRAELI, Raphael. Man of Defiance. A Political Biography of Anwar Sadat. Totowa, New Jersey: Barnes \& Noble Books, 1985.

KHOURI, Fred. The Arab-Israeli Dilemma. New York: Syracuse University Press, 1976.

KISSINGER, Henry. The White House Years. London: Weidenfeld \& Nicolson, 1979.

KNYAZEV, Alexandr Grigoryevich. Egipet posle Nasera, 1970 - 1980 [Egypt after Nasser]. Moscow: Nauka Publishing House, 1986.

MAR '̄i, Sayyid. Awrāq siyāsīya [Political Papers]. Vol. III. Cairo: al-Maktab almișrī al-ḥadīt, 1979.

MAZHAR, Sulaymān. Qișṣat aș-ṣirā $\bar{c}^{c}$ bayna as-Sādāt wa rijāl ' Abdannāṣir [Story of the Struggle between as-Sādāt and 'Abdannāṣir's Men]. Cairo: Maktabat Madbūlī, 1997.

OSIPOV, Alexandr Yosifovich. SShA i arabskie strany, 70-e - nachalo 80-ch godov [The USA and the Arab Countries, 1970s and the beginning of 1980s]. Moscow: "Nauka” Publishing House, 1983.

QUANDT, William B. Decade of Decisions. American Policy Toward the Arab-Israeli Conflict, 1967 - 1976. Berkeley, Cal.: University of California Press, 1977.

RAFAEL, Gideon. Destination Peace: Three Decades of Israeli Foreign Policy. A Personal Memoir. London: Weidenfeld and Nicolson, 1981.

RIYĀḌ, Maḥmūd. Mudakkirāt Maḥmūd Riyāẹ (1948 - 1978). Vol. I. Al-baḥt an as-salām .. wa aș-șirā $\overline{\text { fi }}^{\mathrm{l}}$ ash-sharq al-awsat [Memoirs Maḥmūd Riyāḍ. Search for peace ... and the struggle in the Middle East]. Cairo: Dār alMustaqbal al- ${ }^{\mathrm{c}}$ arabī, 1985.

RUBINSTEIN, Alvin Z. Red Star on the Nile. The Soviet-Egyptian Influence Relationship since the June War. Princeton, New Jersey: Princeton University Press, 1977.

As-SĀDĀT, Anwar. Baht $\underline{t}^{c}$ an ad- $\underline{\text { da }}$ t. Qișsat hayāt [In Search of identity. The Story of my Life]. Cairo: al-Maktab al-mișrī al-ḥadịt li-ṭ-țibā $\bar{a}^{\mathrm{c}} \mathrm{a}$ wa-n-nashr, 1978.

SELLA, Amnon. Soviet Political and Military Conduct in the Middle East. London: The Macmillan Press, 1981.

TAYLOR, Alan R. The Arab Balance of Power. New York: Syracuse University Press, 1982.

TYLER, Patrick. Fortress Israel. The Inside Story of the Military Elite who Run the Country and why they Can't Make Peace. New York: Farrar, Straus and Giroux, 2012.

WANNER, Jan. Krvavý Jom Kippur. Čtvrtá a pátá arabsko-izraelská válka ve světové politice [The Bloody Yom Kippur. The fourth and fifth Arab-Israeli War in World Politics]. Prague: Libri, 2002. 